ASPEK REPRODUKSI IKAN CAPUNGAN BANGGAI Pterapogon kauderni Koumans, 1933 DI SELAT LEMBEH

\title{
(Biology Reproduction Of Banggai Cardinal Fish Pterapogon kauderni Koumans, 1933 In Lembeh Strait)
}

\author{
Lolouren Mogontha', Nego E. Bataragoa², Ari B. Rondonuwu²
}

1Program Studi Manajemen Sumberdaya Perairan, Fakultas Perikanan dan IImu Kelautan Universitas Sam Ratulangi, Jl. Kampus Unsrat Bahu, Manado 95115 Sulawesi Utara, Indonesia

2Staf Pengajar Pada Fakultas Perikanan dan IImu Kelautan, Universitas Sam Ratulangi, Jl. Kampus Unsrat Bahu, Manado 95115, Sulawesi Utara, Indonesia

*e-mail :lolouren17@gmail.com

\section{ABSTRACT}

This research was conducted to determine the reproductive aspects of Banggai Cardinal Fish (Pterapogon kauderni) in the Lembeh Strait. Fish samples were obtained by "Small Chang Net' in the Lembeh Strait. The total sample was 150 individuals. Sex Ratio of Pterapogon kauderni in Serena Besar Island 1: 1, in LIPI 1: 1 waters, and in Papusungan waters 1: 1. IKG Pterapogon kauderni in Serena besar location in females obtained $0.26 \pm 0.21$ and in males $0,26 \pm 0.13$. Location of Papusungan, females obtained $1.25 \pm 1.00$ and in males $0.37 \pm 0.16$. Then finally, at the LIPI location, in females obtained $0.64 \pm 1.12$ and in males $0.50 \pm, 69$. Gonad Maturity Levels are classified into three categories, young gonads, mature and salty gonads, with a percentage of $25 \%$ of individual young gonads, $20 \%$ of mature gonads, and $55 \%$ of saline gonads, respectively. Gonadal maturity index in each category of gonad maturity is young gonad 0.23 , mature 2.16 and salin 0.27 . The "Ovarian Fecundity" is $30 \pm 11$ eggs, and the "Fecundity Brooding" fecundity is $48 \pm 16$ eggs.

Key words: Pterapogon kauderni, Sex Ratio, Gonad Marturity, Fekundity

\section{ABSTRAK}

Tujuan penelitian ini untuk mengetahui aspek reproduksi ikan Capungan banggai (Pterapogon kauderni) yang ada di Selat Lembeh. Sampel ikan diperoleh dengan cara ditangkap menggunakan "Small Chang Net" Di Selat Lembeh. Total hasil tangkapan Berjumlah 150 individu. Nisbah kelamin Pterapogon kauderni di Pulau Serena Besar 1 : 1. Di perairan LIPI 1 : 1, dan di Perairan Papusungan 1 : 1. IKG Ikan Pterapogon kauderni di lokasi P. Serena Besar betina diperoleh $0,26 \pm 0,21$ dan pada jantan $0,26 \pm 0,13$. Di lokasi Papusungan, betina diperoleh $1,25 \pm 1,00$ dan pada jantan $0,37 \pm 0,16$. Kemudian terakhir di lokasi LIPI, pada betina diperoleh $0,64 \pm 1,12$ dan pada jantan $0,50 \pm$,69. Tingkat Kematangan Gonad dikelompookan dalam tiga kategori yakni gonad muda, matang dan salin, dengan prosentasi masing-masing $25 \%$ idividu gonad muda, $20 \%$ gonad matang, dan $55 \%$ gonad salin. Indeks kematangan gonad pada setiap kategori kematangan gonad adalah gonad muda 0,23 , matang 2,16 dan salin 0,27 . Fekunditas "Ovarian fecundity" adalah sebanya $30 \pm 11$ butir telur, dan fekunditas "Brooding fecundity" adalah $48 \pm 16$ butir telur.

Kata kunci: Pterapogon kauderni, Nisbah Kelamin, Kematangan Gonad, Fekunditas

\section{PENDAHULUAN}

Ikan hias Capungan banggai merupakan spesies endemik perairan kepulauan Banggai, Sulawesi Tengah (Allen dan Steene, 1996), sehingga dikenal secara luas dengan nama
"Banggai Cardinalfish" (BCF). Sifat hidup ikan ini adalah nokturnal yaitu aktif pada malam hari dan makanan utamanya di alam adalah krustasea yang bersifat plankton. Seperti di Luwuk, Teluk Palu, Selat Lembeh, Tumbak, Kendari,Teluk Gilimanuk, dan
Ambon 
(Kusumawardhani, 2019; Makatipu, 2018; Carlos et al., 2014).

Sifat reproduksi yang unik dari lkan Capungan banggai yaitu dimana ikan jantan dan betina dewasa yang telah matang gonad akan memisahkan diri dari kelompok dan mencari tempat yang cocok dan sesuai untuk kawin. Sebelum sel telur dan sperma dikeluarkan maka mereka akan melakukan beberapa gerakkan yang unik yang dikenal dengan "mating dance" dimana ikan jantan akan bergerak berputar mengelilingi betina dan sebaliknya (Marini, 1996). Setelah itu, ikan betina akan mengeluarkan sel telur yang diikuti oleh ikan jantan mengeluarkan sel sperma. Setelah sel telur dibuahi, ikan jantan akan menangkap sel-sel telur tersebut dan dimasukkan ke dalam mulutnya untuk dierami selama beberapa hari. Setelah telur-telur tersebut menjadi juvenil, ikan dikeluarkan satu persatu dari mulut ikan jantan.

Keberadaan $P$. kauderni di luar habitat aslinya menarik perhatian dimana sebaran saat ini di Selat Lembeh Provinsi Sulawesi Utara sudah mencakup daerah yang cukup luas dengan populasi yang cukup tinggi. Sejak Tahun 2000, sudah dilakukan kajian populasi $P$. kauderni di Selat Lembeh, seperti Erdmann dan Vagelli (2001), (Carlos et al., 2014) dan Makatipu (2018), dan Rondonuwu et al (2020). Namun demikian, informasi tentang beberapa aspek biologi Pterapogon kauderni di luar habitat aslinya yaitu di Selat Lembeh masih kurang, sehingga perlu mengetahui nisbah kelamin, kematangan gonad, dan fekunditas ikan Capungan banggai Pterapogon kauderni di Selat Lembeh.

\section{METODE PENELITIAN}

Pengambilan sampel dilakukan satu kali pada tanggal 5 july 2019. Penangkapan dilakukan dengan "Small Chang Nets" dengan bantuan menyelam SCUBA pada kedalaman 2-5 m dan snorkeling. Kegiatan survey dilakukan pada pagi hingga sore hari, disesuaikan kondisi perairan saat itu. Setelah ikan Capungan banggai Pterapogon kauderni dimasukkan ke dalam kantong, kemudian dimasukkan ke dalam cool box yang berisi es untuk proses pengawetan sampel ikan Capungan banggai Pterapogon kauderni dibawa ke Laboratorium Fakultas Perikanan Unsrat dan dimasukkan ke dalam freezer.
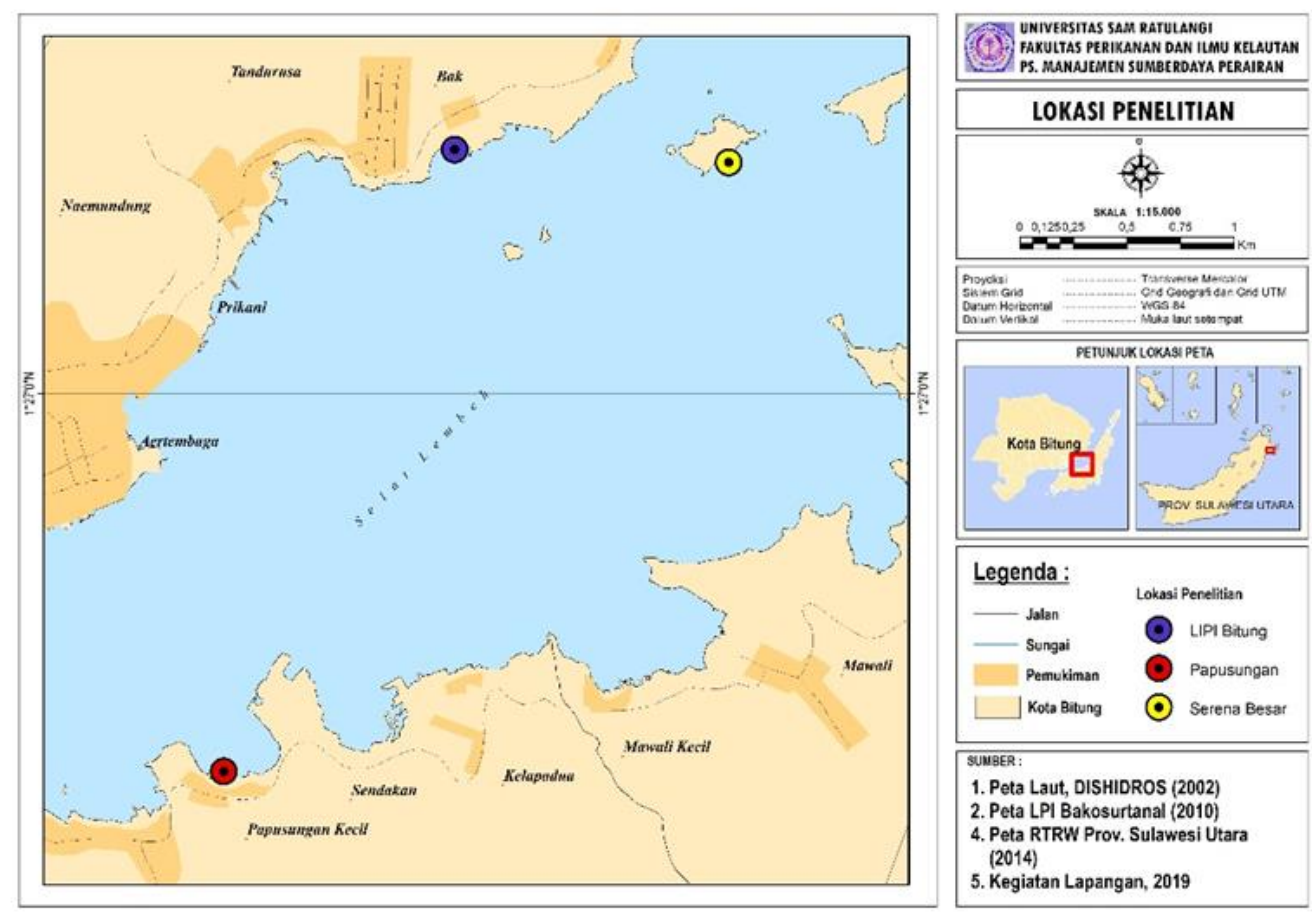

Gambar 1. Peta Tempat Pengambilan Sampel di Selat Lembeh 
Penelitian ini menggunakan metode random sampling dengan memperhatikan kelompok ukuran kecil, sedang dan besar. Untuk memperoleh data nisbah kelamin, fekunditas dan indeks kematangan gonad dilakukan pengambilan data pada sampel berjumlah 50 individu dari tiga tempat. Pengumpulan data meliputi Panjang total dengan menggunakan mistar digital (caliper) dengan tingkat ketelitian 0,01 $\mathrm{mm}$ dan berat tubuh diukur dengan timbangan digital dengan ketelitian 0,05 g. Selanjutnya ikan akan di bedah untuk mengamati gonad jantan dan betina. Setiap gonad diukur beratnya sampai ketelitian 0,01 g.

Pengamatan Tingkat kematangan Gonad, khususnya ikan betina, dikelompokkan dalam tiga kategori (penyederhanaan dari Prihatiningsih dan Hartati, 2012) yaitu: 1) gonad muda, belum nampak butiran telur secara kasak mata dan hanya nampak berupa cairan kental berwarna kuning-oranye, 2) gonad berkembang matang, butiran telur sudah jelas kelihatan secara kasak mata dan 3) gonad mijah atau spent adalah gonad yang telah kosong dan nampak hanya selaput gonad saja, ikan baru selesai memijah.

\section{Analisis Data}

\section{Nisbah Kelamin}

Nisbah kelamin ditentukan berdasarkan jumlah sampel Ikan Capungan banggai jantan dan betina yang diperoleh selama penelitian. Nisbah kelamin yang didasarkan pada jumlah Ikan Capungan banggai jantan dan betina yang tertangkap, dihitung dengan menggunakan rumus sebagai berikut (Omar et al 2015):

$$
\mathrm{NK}=\frac{\sum \mathrm{J}}{\sum \mathrm{B}}
$$

Keterangan:

$\mathrm{NK}=$ nisbah kelamin

$\sum \mathrm{J}=$ jumlah ikan Capungan banggai jantan (ekor)

$\sum \mathrm{B}=$ jumlah ikan Capungan banggai betina (ekor)

\begin{tabular}{ccr}
\multicolumn{1}{c}{ Untuk } & $\begin{array}{c}\text { menguji } \\
\text { perbandingan }\end{array}$ & $\begin{array}{r}\text { apahin } \\
\text { mengikuti }\end{array}$ \\
perbandingan 1: & 1atau tidak, digunakan
\end{tabular}

uji statistik Chi-kuadrat $\left(X^{2}\right)$ sebagai berikut (Zar, 1984):

$$
X^{2} \text { hitung }=\sum(O-E)^{2} / E
$$

Keterangan:

$\mathrm{O}=$ frekuensi pengamatan

$\mathrm{E}=$ frekuensi harapan

dengan hipotesis :

$\mathrm{H}_{0}$ : perbandingan jantan dan betina adalah $1: 1$

$\mathrm{H}_{1}$ : perbandingan jantan dan betina adalah $\neq 1: 1$. Kriteria pengambilan keputusan (Rochmandy, et al., 2012):

Jika $\quad X^{2}$ tabel $(v, \alpha) \geq X^{2}$ hitung terima $\mathrm{H}_{0}$

$X^{2}$ tabel $(v, \alpha)<X^{2}$ hitung tolak $\mathrm{H}_{0}$ atau terima $\mathrm{H}_{1}$

Nilai $X^{2}(v, \alpha)$ dapat dilihat pada table "Critical Values of the Chi-Square Distribution".

\section{Indeks Kematangan Gonad}

Menurut Effendi (2002), indeks kematangan gonad (IKG) dihitung dengan membandingkan bobot gonad dengan bobot tubuh ikan tersebut dikalikan 100 rumus yang digunakan adalah sebagai berikut :

$$
\text { IKG }(\%)=\frac{B G}{B T} \times 100
$$

Keterangan :

IKG = Indeks Kemtangan Gonad (\%)

$B G=$ Berat Gonad Ikan (g)

$\mathrm{BT}=$ Berat tubuh Ikan (g)

\section{Fekunditas}

Penentuan fekunditas dilakukan dengan menjumlah telur pada ukuran yang berbeda-beda pada ikan Capungan banggai Pterapogon kauderni, yaitu mulai dari ukuran kecil, sedang, dan besar. Kemudian hasil fekunditas dari setiap kelas ukuran digambar dalam histogram.

\section{HASIL DAN PEMBAHASAN}

\section{Nisbah Kelamin}

Nisbah kelamin ikan jantan dan ikan betina di alam diperkirakan mendekati 1,00:1,00, yang menunjukkan jumlah ikan betina dan jantan yang tertangkap relatif hampir sama banyaknya (Ball \& Rao, 1984). Nisbah kelamin pada ikan penting diketahui karena berpengaruh terhadap kestabilan populasi ikan tersebut di alam. Berdasarkan pengambilan sampel lkan Capungan banggai Ptreapogon kauderni 
disetiap lokasi diperoleh sebanyak 50 individu. Lokasi pertama yaitu Pulau Serena Besar terdiri atas 29 individu ikan jantan dan 21 individu ikan betina. Lokasi kedua yaitu di depan kantor UPT Lokasi LIPI terdiri atas 22 individu ikan jantan dan 28 individu ikan betina. Lokasi terakhir yaitu di perairan depan Kelurahan Papusungan teridiri atas 23 individu ikan jantan dan 27 individu ikan betina.

Tabel 1. Nisbah Kelamin Ikan Capungan banggai di Pulau Serena Besar

\begin{tabular}{ccccccc}
\hline Kelamin & $\mathbf{O}$ & $\mathbf{E}$ & $\mathbf{O} / \mathbf{E}$ & $\mathbf{O}-\mathbf{E}$ & $(\mathbf{O}-\mathbf{E})^{\wedge} \mathbf{2}$ & $(\mathbf{O}-\mathbf{E})^{\wedge} \mathbf{2} / \mathbf{E}$ \\
\hline Jantan & 29 & 25 & 1,16 & 4 & 16 & 0,64 \\
Betina & 21 & 25 & 0,84 & -4 & 16 & 0,64 \\
Jumlah & 50 & 50 & 2 & 0 & 32 & 1,28 \\
\hline$X^{2}$ hitung = 1,28; $X^{2}$ tabel $(0.05 .1)=34,7643 ; X^{2}$ tabel $(0.05 .1) \geq X^{2}$ hitung terima $\mathrm{H}_{0}$ yaitu \\
perbandingan jantan dan betina di Pulau Serena Besar $1: 1$
\end{tabular}

Tabel 2. Nisbah Kelamin Ikan Capungan banggai di depan Perairan LIPI

\begin{tabular}{ccccccc}
\hline Kelamin & $\mathbf{O}$ & $\mathbf{E}$ & $\mathbf{O} / \mathbf{E}$ & $\mathbf{O}-\mathbf{E}$ & $(\mathbf{O}-\mathbf{E})^{\wedge} \mathbf{2}$ & $(\mathbf{O}-\mathbf{E})^{\wedge} \mathbf{2} / \mathbf{E}$ \\
\hline Jantan & 22 & 25 & 0,88 & -3 & 9 & 0,36 \\
Betina & 28 & 25 & 1,12 & 3 & 9 & 0,36 \\
Jumlah & 50 & 50 & 2 & 0 & 18 & 0,72 \\
\hline
\end{tabular}

$X^{2}$ hitung $=0,72 ; X^{2}$ tabel $(0.05 .1)=34,7643 ; X^{2}$ tabel $(0.05 .1) \geq X^{2}$ hitung terima $\mathrm{H}_{0}$ yaitu perbandingan jantan dan betina di perairan depan LIPI 1:1

Tabel 3. Nisbah Kelamin Ikan Capungan banggai di Kelurahan Papusungan

\begin{tabular}{ccccccc}
\hline Kelamin & $\mathbf{O}$ & $\mathbf{E}$ & $\mathbf{O} / \mathbf{E}$ & $\mathbf{O}-\mathbf{E}$ & $\mathbf{( 0 - E ) \wedge \mathbf { 2 }}$ & $(\mathbf{O}-\mathbf{E})^{\wedge} \mathbf{2} / \mathbf{E}$ \\
\hline Jantan & 23 & 25 & 1,08 & 2 & 4 & 0,16 \\
Betina & 27 & 25 & 0,92 & -2 & 4 & 0,16 \\
Jumlah & 50 & 50 & 2 & 0 & 8 & 0,32 \\
\hline
\end{tabular}

$X^{2}$ hitung $=0,32 ; X^{2}$ tabel $(0.05 .1)=34,7643 \quad ; X^{2}$ tabel $(0.05 .1) \geq X^{2}$ hitung terima $\mathrm{H}_{0}$ yaitu perbandingan jantan dan betina di Kelurahan Papusungan $1: 1$

Berdasarkan Tabel 1, 2, dan 3, secara keseluruhan nisbah kelamin Ikan Capungan banggai Pterapogon kauderni menunjukkan bahwa nisbah kelamin yang diperoleh seimbang atau mengikuti pola 1:1. Nisbah kelamin ikan jantan dan ikan betina di alam diperkirakan mendekati 1:1 yang menunjukkan jumlah ikan betina dan jantan yang tertangkap relatif hampir sama banyaknya (Ball dan Rao, 1984).

Analisis chi-kuadrat menggunakan $\alpha=0,05$ diperoleh nilai $X^{2}$ hitung $=1,28$ di Pulau Serena Besar, nilai $X^{2}$ hitung $=0,72$ di Perairan LIPI, nilai $X^{2}$ hitung $=0,32$ di Desa Papusungan, dan kemudian nilai $X^{2}$ tabel $(0,05.1)=34,7643$ ( $X^{2}$ table $\geq X^{2}$ hitung) sehingga $\mathrm{H}_{0}$ diterima bahwa tidak terdapat perbedaan rasio antara ikan jantan dan ikan betina di tiga titik lokasi Selat Lembeh. Namun demikian walaupun uji statistik menunjukkan perbandinagan jantan betina 1:1 namun terdapat kecenderungan jumlah ikan betina lebih banyak dari ikan jantan. Berbeda dengan itu Ndobe et al., (2013), memeiliki data yang jumlah individu jantan lebih banyak dari individu betina dan menyimpulkan bahwa rasio berbeda nyata dengan $1: 1$.

\section{Kematangan Gonad}

Perkembangan gonad ikan secara garis besar terdiri atas dua tahap yaitu tahap pertumbuhan dan tahap pematangan (Lagler et al., 1977). Indeks Kematangan Gonad (IKG) merupakan suatu cara untuk mengetahui perkembangan gonad pada setiap kematangan gonad secara kuantitatif. Data IKG ikan Capungan banggai Pterapogon kauderni jantan dan betina sebagai mana yang ditampilkan dalam Tabel 4. 
Berdasarkan Tabel 4 , nilai IKG tertinggi di lokasi Serena Besar pada ikan jantan yaitu 0,96 , sedangkan nilai IKG terendah 0,09 dengan $0,27 \pm 0,21$. Nilai IKG tertinggi pada ikan betina 0,71, sedangkan terendah yaitu 0,11 , dengan $0,26 \pm 0,14$. Di lokasi Papusungan nilai IKG tertinggi pada ikan jantan yaitu 0,83 , sedangkan nilai IKG terendah 0,16 , dengan $0,38 \pm 0,17$. Kemudian nilai IKG tertinggi pada ikan betina yaitu 10,65, sedangkan terendah yaitu 0,14 , dengan $1,26 \pm 1,00$. Terakhir di lokasi LIPI, nilai IKG tertinggi pada jantan yaitu 3,15, sedangkan terendah nilai IKG terendah yaitu 0,10 , dengan $0,51 \pm 0,70$. Kemudian nilai IKG tertinggi pada ikan betina yaitu 5,16 , sedangkan yang terendah yaitu 0,10 , dengan $0,73 \pm 1,49$.

Tabel 4. Indeks Kematangan Gonad Ikan Capungan banggai di Selat Lembeh ( $\mathrm{n}=$ jumlah individu; $\mathrm{SD}=$ Standar deviasi)

\begin{tabular}{|c|c|c|c|c|c|c|c|}
\hline \multirow[b]{2}{*}{ No } & \multirow[b]{2}{*}{ Lokasi } & \multicolumn{3}{|c|}{ Jantan } & \multicolumn{3}{|c|}{ Betina } \\
\hline & & $\mathrm{N}$ & Kisaran & $\begin{array}{c}\text { Rata-rata } \\
\pm \text { SD }\end{array}$ & $\mathrm{n}$ & Kisaran & $\begin{array}{c}\text { Rata-rata } \pm \\
\text { SD }\end{array}$ \\
\hline 1 & Serena Besar & 29 & $0,09-0,96$ & $0,27 \pm 0,21$ & 21 & $0,11-0,71$ & $0,26 \pm 0,14$ \\
\hline 2 & Papusungan & 27 & $0,16-0,83$ & $0,38 \pm 0,17$ & 23 & $0,10-5,16$ & $1,26 \pm 1,00$ \\
\hline 3 & LIPI & 22 & $0,10-3,15$ & $0,51 \pm 0,70$ & 28 & $0,14-10,65$ & $0,65 \pm 1,12$ \\
\hline 4 & Gabungan & 78 & $0,16-3,15$ & $0,38 \pm 0,41$ & 72 & $0,10-10,65$ & $0,73 \pm 1,49$ \\
\hline
\end{tabular}

Tabel 5. Jumlah Individu (n) dan Presentasi Jumlah Individu (\%) Tingkat Kematangan Gonad (TKG) ikan Capungan banggai P.kauderni di Selat Lembeh.

\begin{tabular}{|c|c|c|c|c|c|c|c|c|c|}
\hline \multirow{2}{*}{$\begin{array}{l}\text { No } \\
1\end{array}$} & \multirow{2}{*}{$\begin{array}{c}\text { TKG } \\
\text { Gonad Muda }\end{array}$} & \multicolumn{2}{|c|}{$\begin{array}{c}\text { Serena } \\
N\end{array}$} & \multicolumn{2}{|c|}{$\begin{array}{c}\text { Papusungan } \\
\% \\
\end{array}$} & \multicolumn{2}{|c|}{$\begin{array}{c}\text { LIPI } \\
\mathrm{n}\end{array}$} & \multicolumn{2}{|c|}{$\begin{array}{c}\text { Gabungan } \\
\%\end{array}$} \\
\hline & & 2 & 10 & 6 & 27 & 10 & 36 & 18 & 25 \\
\hline 2 & Gonad Matang & 0 & 0 & 8 & 36 & 6 & 33 & 14 & 20 \\
\hline 3 & Gonad Salin & 19 & 90 & 8 & 36 & 12 & 43 & 39 & 55 \\
\hline & Total & 21 & 100 & 22 & 100 & 28 & 100 & 71 & 100 \\
\hline
\end{tabular}

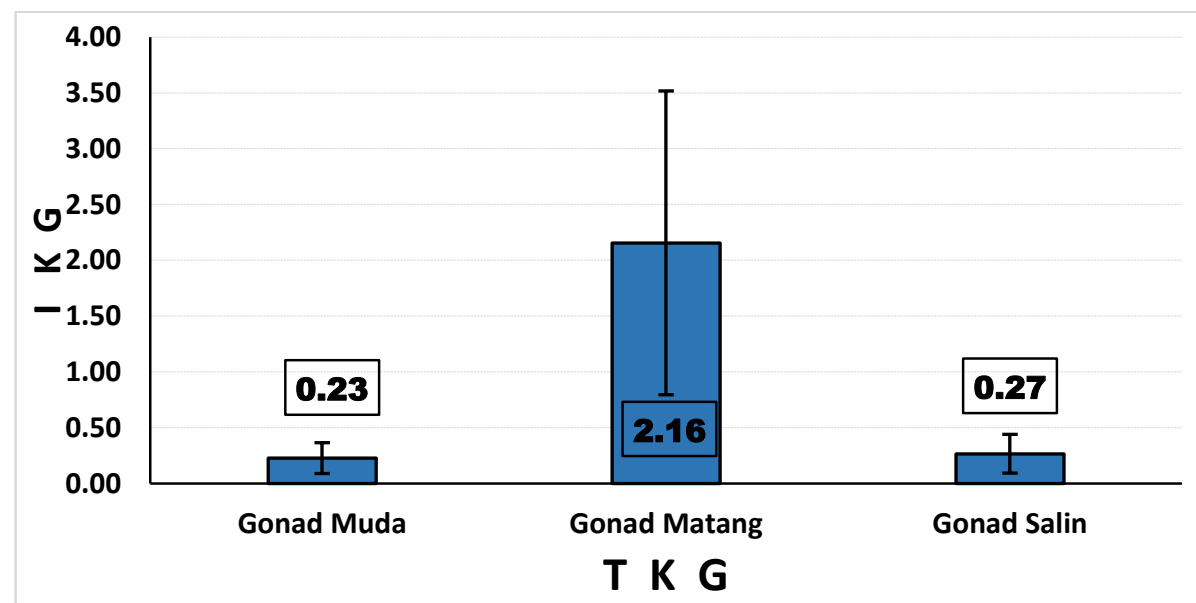

Gambar 2. Indeks Kematangan Gonad P.cauderni betina di Selat Lembeh (Garis vertikan menunjukkan SD, dan angka menunjukkan nilai IKG).

Berdasarkan penelitian (Tabel 5) di lokasi Serena Besar terdapat 2 individu tergolong gonad muda dengan presentasi 10\%, dan Gonad Salin terdapat 19 individu dengan presentasi $90 \%$. Lokasi Papusungan terdapat 6 individu tergolong gonad muda dengan presentasi $27 \%$, gonad matang terdapat
8 individu dengan presentasi $36 \%$, dan gonad salin terdapat 8 individu dengan presentasi $36 \%$. Kemudian di lokasi perairan LIPI terdapat 10 individu tergolong gonad muda dengan presentasi $26 \%$, gonad matang terdapat 6 individu dengan presentasi 33\%, dan 12 individu tergolong gonad salin dengan 
TKG 43\%. Secara Keseluruhan Prosentase Tingkat Kematangan Gonad di Selat Lembeh (Gambar 3; Tabel 5) Ikan Capungan banggai pada saat penelitian pada 5 Juli 2019 sebagian besar telah memijah (TKG Gonad Salin) sebesar $55 \%$ dan $20 \%$ ikan siap untuk memijah (gonad matang) serta $25 \%$ gonad dalam tahap perkembangan (gonad muda).
Indeks kematangan gonad pada $P$. kauderni pada setiap kategori Tingkat Kematangan Gonad menyunjukkan variasi yang besar atara gonad muda dan gonad salin dengan gonad matang (Gambar 3). Dari gambar ini nampak bahwa TKG pada gonad muda $(0,23)$ dan gonad salin $(0,27)$ jauh lebih kecil dari TKG gonad matan sebesar 2,16.

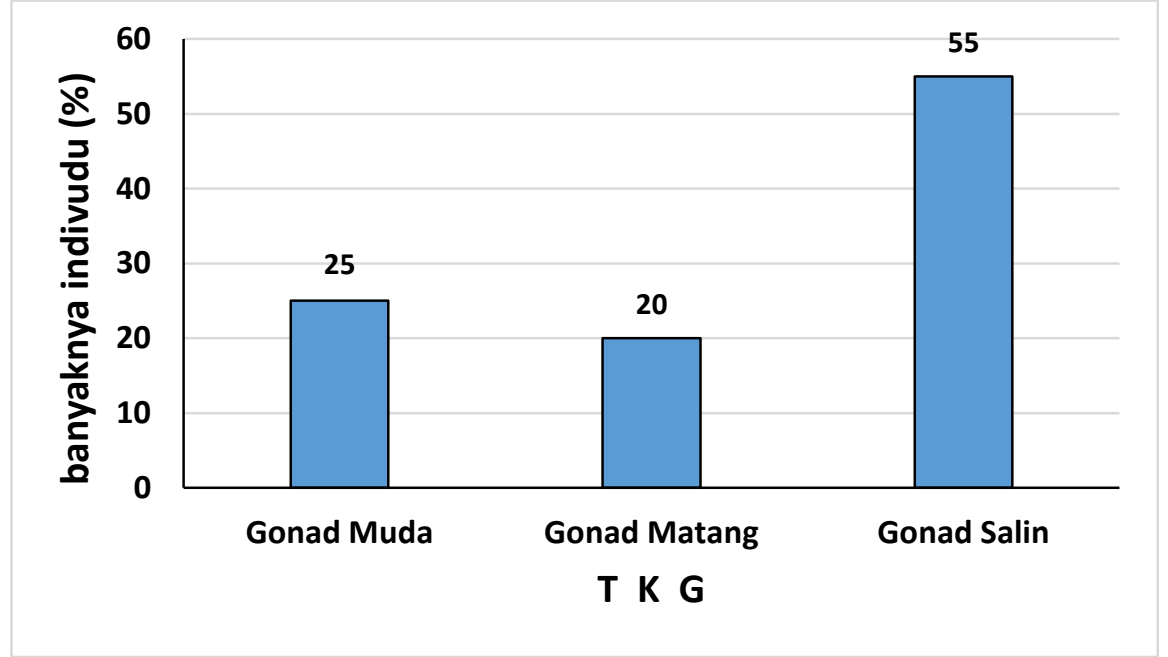

Gambar 3. Prosentase banyaknya individu pada setiap TKG P.cauderni di Selat Lembeh.

\section{Fekunditas}

Fekunditas ikan Capungan banggai dikelompokkan dalam dua bagian yaitu "Ovarian fecundity" yaitu jumlah telur matang yang ada dalam ovarium sebelum dikeluarkan dalam pemijahan dan "Brooding fecundity" yaitu jumlah telur yang sedang dierami di dalam mulut (Begenal, 1978).

\section{"Ovarian fecundity"}

Dalam penelitian ini ditemukan 76 individu betina dari ketiga lokasi, namun hanya 14 individu yang ditemukan mengandung telur. Dengan perincian enam individu dari perairan sekitar di depan kantor UPT Lokasi LIPI dan delapan individu di perairan depan Kelurahan Papusungan. Contoh ikan dari perairan sekitar Pulau Serena Besar tidak ditemukan ada yang mengandung telur, namun terdapat ikan jantan yang mengerami telur dalam mulutnya. Banyaknya telur 11 ditemukan pada ikan dengan ukuran panjang total $75,12 \mathrm{~mm}$ dan 45 butir pada ikan dengan ukuran $71,34 \mathrm{~mm}$. Tabel 7 menunjukkan ratarata jumlah telur pada setiap kelas ukuran, di mana kisaran ukuran ikan 70$74 \mathrm{~mm}$ memiliki fekunditas terbesar yakni 34 butir. Secara keseluruhan rata-rata fekunditas (rata-rata \pm Standar Deviasi) adalah sebanya $30 \pm 11$ butir telur. Di perairan Kepulauan Banggai Ndobe et al., (2013) mengungkapkan bahwa fekunditas ralatif Ikan Capungan banggai rata-rata 50 butir, dan Allen (2000) mengungkapkan fekunditas absolut berkisar antara 12-40 butir telur.

\section{"Brooding fecundity"}

Sebagaimana diketahui bahwa ikan capungan banggai adalah parental care jantan melindungi telur dan anak, dan ditemukan beberapa ikan jantan menegerami telur di mulut. Dari 74 individu jantan yang diamati dalam penelitian ini, hanya delapan individu jantan yang ditemukan mengerami telur dalam mulutnya sebagai mana yang 
ditampilkan dalam Tabel 8. Dari tabel ini jumlah telur yang dierami ikan jantan (Rata-rata \pm Standar Deviasi) adalah $48 \pm 16$ butir telur dengan kisaran data 2264 butir telur. Dari data "Brooding fecundity" ini jika dibandingkankan dengan "Ovarian fecundity" Nampak bahwa terdapat kecenderungan satu ekor ikan jantan akan mengerami telur dari beberapa (lebih dari satu) individu betina. Hal ini nampaknya sejalan dengan data dalam penelitian ini dimana terdapat kecenderungan ikan jantan lebih sedikit dari ikan betina, tetapi bertolakbelakang dengan data Ndobe et al., (2013) dimana ikan betina lebih banyak dari ikan jantan.

Tabel 6. Rata-rata "ovarian fecundity" Ikan Capungan banggai $P$.kauderni pada setiap kelas ukuran di Selat Lembeh. (N, adalah jumlah ikan sampel)

\begin{tabular}{cccc}
\hline No. & Kelas Ukuran $(\mathbf{m m})$ & $\mathbf{N}$ & $\begin{array}{c}\text { Rata-rata } \\
\text { Fekunditas }\end{array}$ \\
\hline $\mathbf{1 .}$ & $58-64$ & 1 & 32 \\
$\mathbf{2 .}$ & $65-69$ & 2 & 32 \\
$\mathbf{3 .}$ & $70-74$ & 2 & 34 \\
$\mathbf{4 .}$ & $75-79$ & 8 & 28 \\
$\mathbf{5 .}$ & $80-84$ & 1 & 31 \\
& & Rata-rata & 30 \\
& & Standar Deviasi & 10 \\
\hline
\end{tabular}

Tabel 7. "Brooding fecundity" Ikan Capungan banggai di Selat Lembeh.

\begin{tabular}{lcc}
\hline \multicolumn{1}{c}{ Lokasi } & Ukuran ikan & Fekunditas \\
\hline \multirow{2}{*}{ Serena Besar } & 76,78 & 56 \\
& 70,34 & 33 \\
LIPI & 73,71 & 64 \\
& 78,84 & 64 \\
Papusungan & 78,86 & 22 \\
& 81,44 & 37 \\
& 87,64 & 62 \\
& 82,10 & 48 \\
& Rata-Rata & 48 \\
\hline
\end{tabular}

\section{KESIMPULAN}

Nisbah kelamin ikan Capungan banggai di lokasi Serena Besar, LIPI dan Papusungan adalah 1 : 1., Nilai Indeks kematangan gonad pada P.cauderni dari keseluruhan lokasi di depan kantor UPT Lokasi LIPI, di perairan depan Kelurahan Papusungan, dan di Pulau Serena Besar adalah 0,3 untuk gonad muda, 2,13 pada gonad matang, dan 0,27 pada gonad salin. Kemudian banyaknya individu pada setiap TKG P.cauderni pada keseluruhan lokasi di depan kantor UPT Lokasi LIPI, di perairan depan Kelurahan Papusungan, dan di Pulau Serena Besar adalah, gonad muda $25 \%$, gonad matang $20 \%$, dan gonad salin $50 \%$. "Ovarian fecundity" atau betina yang mengandung butir telur pada P.cauderni berjumlah 14 individu, dan memiliki $30 \pm 10$ butir telur. "Brooding fecundity" atau individu jantan yang mengerami telur dalam mulutnya berjumlah 8 individu, dan memiliki ratarata $48 \pm 16$ butir telur.

\section{DAFTAR PUSTAKA}

Allen, G.R., 2000. Threatened fishes of the world : Pterapogon Koumans, 1933 (Apogonidae). Environmental Biology of Fishes, 57: 142.

Allen, G.R., R.C. and Steene, 1995. Notes On The Ecology And Behaviour of The Indonesian Cardinalfish (Apogonidae Pterapogon kauderni Koumans) Rev. Fr. Aquariol, 22: 7-9.

Bagenal, T.B. (1978) Methods for assessment of fish production in 
freshwaters. IBP Handbook No. 3, Blackwell Scientific Publication, 3rd Edition, London, 300 pages.

Carlos, N. S. T, A.B.Rondonuwu., dan V. N. R. Watung, 2014. Distribusi dan Kelimpahan Pterapogon kauderni Koumans, 1933 di Selat Lembeh Bagian Timur, Kota Bitung. Jurnal Ilmiah Platax. Vol 2 : (3) Manado hal $121-126$.

Ball, D. V., K. V. Rao. 1984. Marine fisheries. Tata Mc. Graw-Hill Publishing Company, Limited New Delhi. 521 p.

Erdmann, M. V., dan A. Vagelli, 2001. Banggai cardinalfish invade Lembeh Strait. Coral Reefs 20(3): 252-253.

Effendi, M.I. 2002. Biologi Perikanan. Yogyakarta: Yayasan Pustaka Nusatama. Fakultas Perikanan, Bogor.

Lagler, K.F., J.E. Bardach and R.R. Miller. 1977. Ichthyology. John Wiley and Sons, NewYork.

Makatipu, P. Ch., 2018. Status Ikan Capungan "Banggai Cardinalfish" (Pterapogon kauderni) Di Selat Lembeh, Kota Bitung, Sulawesi Utara. Prosiding Seminar Pengelolaan Berkelanjutan Sumberdaya Laut dan Pesisir Sulawesi Utara dan Sekitarnya. Halaman 110 - 121.

Ndobe S., Soemarno; E.Y. Herawati; D. Setyohadi, 2013. Life History Of Banggai Cardinalfish, Pterapogon kauderni (Actinopterygii: Perciformes: Apogonidae), From Banggai Islands And Palu Bay, Sulawesi, Indonesia Acta. Ichthyol. Piscat. 43 237-250.
Ndobe,S., I.Widastuty dan A.Mooru. 2013. Seks Ratio dan pemangsaan terhadap rekrut pada ikan hias Banggai Cardinal Fish (Pterapogon kauderni).

Omar A.S. B., M. Nur, M. T. Umar, M. A. Dahlan dan S. Kune. 2015. Nisbah Kelamin Dan Ukuran Pertama Kali Matang Gonad Ikan Endemik Pirik (Lagusia micracanthus Bleeker, 1860) Di Sungai Pattunuang, Kabupaten Maros, Dan Sungai Sanrego, Kabupaten Bone, Sulawesi Selatan. Seminar Nasional Tahunan XII Hasil Penelitian Perikanan dan Kelautan, 08 Agustus 2015.

Rochmandy, Andy Omar, S. Bin, Lodewyck S. Tandipayuk. Nisbah Kelamin Dan Ukuran Pertama Matang Gonad Kerang Lumpur Anodontia endetula, Linnaeus 1758 di Pulau Tobea, Kecamatan Napabalano Kabupaten Muna. Jurnal IImiah agribisnis dan Perikanan (agrikan UMMU): 5(2) 25-31.

Rondonuwu, A.B., L.J. L. Lumingas, N.E. Bataragoa, S.B. Pratasik, F.F. Tilaar, M.S. Salaki. Mitochondrial CO1 sequences of Banggai cardinal fish (BCF) from Lembeh Strait, North Sulawesi, Indonesia. AACL Bioflux, 2020, Volume 13, Issue 2.http://www.bioflux.com.ro/aacl

Vagelli, A.A., 2011. The Banggai cardinalfish: natural history, conservation, and culture of Pterapogon kauderni. WileyBlackwell, UK. 203 pp. 